\title{
AN EMPIRICAL INVESTIGATION OF FACTORS INFLUENCING GREEN PRODUCT PURCHASE INTENTION OF MILLENNIALS
}

\section{Mohd Maaz Khan Sherwani ${ }^{1 *}$, Mohd. Azmi khan², Mohd. Amanullah ${ }^{3}$ and Amgad S. D. Khaled ${ }^{4}$}

1 Student, Aligarh Muslim University, Aligarh

2, 3 Assistant Professor, Institute of Technology \& Management, Aligarh

4 Dep. of Management infomation system, Al-Rowad University, Taiz, Yemen

Received: 05.07.2021 • Accepted: 09.07.2021 • Published: 16.07.2021 • Final Version: 16.07.2021

\begin{abstract}
This paper looks into the sustainability aspect from millennials point of view and highlight the factors which influence their buying decision to prefer green or eco-friendly products over traditional products. Initially, those factors were identified which have an impact on green product purchase intention and their relationship is assessed. To explore the factors, an extensive literature review was conducted and three factors green brand knowledge, attitude towards green brand and willingness to pay were found to be pertinent. This study adopts a conclusive research design to investigate the impact of these factors on green product purchase intention. Data was analyzed through exploratory factor analysis, confirmatory factor analysis (CFA) and structural equation modeling (SEM) on a sample size of 376. Results of study showed that all the constructs namely green brand knowledge, attitude towards green brand and willingness to pay have direct and positive effect on green product purchase intention.
\end{abstract}

Keywords: Green brand knowledge, attitude towards green brand, willingness to pay, green product purchase intention, millennials

\section{Introduction}

Apart from targeting profit maximization, companies are focusing on generating novel ideas and thinking to position their green brand in an environment-friendly manner to stay competitive and gain consumers' trust. In this manner, organizations can achieve sustainability in their operations and protect the environment. Environment-friendly brand is termed as "a brand, which offers a significant eco-advantage over its competitors and is able to attract consumers who set a high priority on making green purchases" (Grant, 2008). As stated by Hartmann and Ibanez (2006), "a green brand entails a set of attributes and benefits associated with reduced adverse environmental impact and the creation of a positive impression on consumers by raising their environmental concern". Eco-friendly consumer is referred to one who spends extra money to buy environment-friendly products and is concerned about eco-friendliness (Norazah and Norbayah, 2015a). Customers have transmitted their emerging apprehension for nature with the need for green or environment-friendly products. The campaign of 'going green' has extended globally because of strengthening knowledge related to environmental issues in an improved manner (Soyez, 2012; Norazah, 2013a; Thogersen et al., 2015). Number of firms are working on the subject and performing hard to protect the environment. 
To protect the nature, various organizations in the different industries have started acquiring green technologies that preserve raw material and lessen the outflow of greenhouse gases (Oliver and Lee, 2010; Marcus and Fremeth, 2009). Previous researches by Juwaheer et al. (2012), Yadav and Pathak (2016), Hartmann and Ibanez (2006) and Konuk (2015) showed that many researches had been done on ecological marketing in developed nations. However, very few studies have been done on green buying behavior and green branding in emerging economies. Joshi and Rahman (2015) suggested that more researches are needed in addition to previous researches in the developing nations to determine the effect of eco-friendly awareness on green purchase intention.

\section{Literature Review}

\subsection{Attitude towards Green Brands (ATGB)}

Attitude towards a brand is related to the customers' inclination and whole assessment of a brand, which shows their preferences (Solomon, 2014). Previously researchers stated that buying choices are generally founded on the customers' ecological attitude (Gupta and Ogden, 2009; Felix and Braunsberger, 2016). Attitude is the basic characteristic that makes consumer attitude and affects their buying decision of green items (Thogersen et al., 2015; Schiffman and Wisenblit, 2014). Earlier researches on environment-friendly or eco-friendly products have shown the customers' behavior with respect to environmental attitude, their awareness of eco-friendliness and green product purchase intention (Aman et al., 2012; Barber et al., 2009; Flamm, 2009). Yadav and Pathak (2016) stated that consumer behavior towards environment-friendly products affects the intention of consumer to buy green products. Similar to these studies, Paul et al. (2016) said that the behavior of Indian consumers makes different assumption on their purchase intention of green products. Mostafa (2009) said those consumers who have sound behavior towards eco-friendly products are appropriate to build up a strong tendency to buy environment-friendly products by alluding to green brands, and also depend on positioning of environment-friendly brand. Teng (2009) determined that consumers with a sound behavior towards a specific brand have a strong purchase intention to purchase the branded products. Therefore, on the basis of past literature this study in this manner assumes that:

\section{H1: Attitude towards green brands have a direct and positive impact on green product purchase intention.}

\subsection{Green Brand Knowledge (GBK)}

Knowledge about green brand is described as "a green brand node in the consumers' memory with which a variety of associations are linked to environmental commitment and environmental concerns" (Keller, 1993). Knowledge of green brand gives details of the products that have exceptional brand characteristics and its advantages to the complete atmosphere to the customer. Brand knowledge is the image of a brand and knowledge related to brand (Keller, 1993). Consciousness regarding brand is robustness of the brand association held in customer mind, while image of a brand indicates to strong, exclusive, and positive brand relationship in the customer mind (Keller, 1993). Customers hope for authentic details about ecological issues to increase their knowledge of green brands and encourage the purchases of eco-friendly products (Geyer-Allely and Zacarias-Farah 2003; Ganapathy et al., 2014; Thongplew et al., 2014). Various researches have revealed that ecological information certainly affects customer objective and actual purchase of green items (Norazah, 2013a; 2013b; 2013c; Chen and Chang, 2012; Mostafa, 2009; Pagiaslis and Krontalis, 2014; Peattie, 2010; Eze and Ndubisi, 2013; Pathak, 2016; Paul et al. 2016). Previous green marketing researches have noticed that consumers' moral behavior towards green items could impact their buying objective (Laroche et al., 2001; Chang and $\mathrm{Wu}, 2015)$. Wolsink (2007) couldn't describe any connections between ecological information and intention to purchase green products. Connell (2010) and Padel \& Foster (2005) suggested that knowledge indirectly affect the buying behavior of a consumer to buy eco-friendly products. 
Researches in the past by Fraj-Andres and Martinez-Salinas (2007) highlighted that knowledge related to environment-friendly products regulate the impact of consumers' environmental behavior towards green attitude. Furthermore, consumers with extreme knowledge of the environment have a good proecological behavior and have a strong objective to buy eco-friendly products (Huang et al., 2014; Rokicka, 2002).

\section{H2: Green brand knowledge have a direct and positive impact on green product purchase intention.}

\subsection{Willingness to Pay (WTP)}

Willingness to pay (WTP) some extra premium for eco-friendly products is essential for organizations to keep themselves motivated and proceed further in sustainable way of living. Past researchers have studied the factors that affect their purchase intention and concluded that consumers agree to pay higher prices for green or environment friendly products. Environmental consciousness is an influencing element for consumers' willingness to pay. Paying a premium for green products encourage their production of green products and recover the cost of their extra efforts. Studies in the past have attempted to assess the consumers' attitude to pay more for green products (Le Gall-Elly. M, 2009.). Numerous researches have been considered willingness-to-pay for green products or sustainable items in the background of developed economies (Hansala et al., 2008; Galarraga et al., 2011). Studies have also shown the tendency of customers to pay more for green products (Reynolds et al., 2012; Erikson. C, 2004).

Willingness to pay measures consumers' readiness to pay extra amount for the purchase of ecofriendly product (Laroche et al., 2001; Cheah \& Phau, 2011). Generally, environment-friendly products have higher prices than standard products because of the adoption of environment-friendly technologies, packaging, labelling, process of production, etc. Previous studies showed that consumers' are willing to pay extra premium for the purchase of green products in comparison to normal product (Coddington, 1990; Essoussi \& Linton, 2010; Myburgh-Louw et al., 1993; Tsen et al., 2006; Bowmen, 2007; Okada \& Mais, 2010; Cheah \& Phau, 2011; Moser, 2015). Coddingtoin (1990) in his study, highlighted that the majority of the respondents are willing to pay 5-10\% extra premium for the purchase of green products. Myburgh- Louw et al. (1993) also showed that majority of the respondents were ready to pay extra sum of money up to $40 \%$ in order to buy eco-friendly products. Tsen et al. (2006) suggested that willingness to pay affects green product purchase intention. Bowmen (2007) highlighted that half of the respondents were ready to pay extra-premium up to $10 \%$ for the purchase of environment-friendly products. Moser (2015) concluded that paying with willingness is one of the main factors of consumers' behavior towards purchase of green products. Various researchers have paid attention to willingness to pay (WTP) in developed economies (Tsen et al., 2006; Essoussi \& Linton, 2010; Okada \& Mais, 2010; Moser, 2015) but less attention has been paid on this factor in developed economies.

\section{H3: Willingness to pay have a direct and positive impact on green product purchase intention.}

\subsection{Green Product Purchase Intention (GPPI)}

In the 1970s, various studies have been done on purchase intention of consumer-related to ecofriendly behavior. Numerous factors including values, demographic, knowledge/belief, motivation, needs and attitude revealed to drive consumer purchase intention for buying green products (Bui, 2005). However, it was found that limited number of studies have been done in the area of green product purchase intention in non-metropolitan cities (Tanner and Kast, 2003; Lee, 2008; Cheah, 2009). 
Studies related to green marketing in Asian nations are comparatively less while comparing with western nations (Lee, 2008). Green purchase intention is considered likeliness of consumers to buy environment-friendly product over a conventional product (Nik Abdul Rashid, 2009). Chan (2001) described green purchase intention as a particular sort of ecological attitude that consumers do to express their apprehension to nature. Green product purchase intention is an important factor to make prediction about customer attitude (Fishbein and Ajzen, 1975). Intention of customers has been used as an alternative for actual behavior (Follows and Jobber, 2000). In the purchase intention process, the customer makes brand evaluation and subject to consideration during assessment stage (Kotler and Armstrong, 2001)

For the purchase intention of eco-friendly products, Iman and Zainuddin (2011) stated that the state laws did not have any impact on purchase intention or ecological behavior. Ng and Paladino (2009) empirically conducted the study among young customers in the Australian region on the purchase intention on eco-friendly cell phones or mobiles. The investigation shows that ecological knowledge is a crucial factor in building up green purchases. Lee (2008) and Punitha \& Rahman (2011) studied factors such as green purchase intention, ecological behavior and government initiative related to Theory of Respond Action (TRA) model to confirm the purchase of green products among consumers of Malaysia. As per Allport (1935), objects and situations which are related to individual responses are influenced by the attitude of a person caused by mental and neural state. Attitude represents the likeliness of consumers towards any product or situation (Blackwell et al., 2006). Schultz and Zeleny (2000) state that the behavior of an individual towards the environment shows his concern for surroundings. From the previous literature, it was observed that attitude towards green brand is the key constructs for measuring consumer behavior towards green product purchase intention. The purchase intention of a consumer is affected by various factors such as price, quality, GBK, WTP, ATGB. Various researchers have studied attitude towards green brand in different context (Kirmani \& Khan, 2016; Laroche et al., 2001; Akehurst et al., 2012; Mourad and Ahmed, 2012; Iravani et al., 2012; Hassan, 2014; Laroche et al., 2001; D’ Souza et al, 2006; D' Souza et al., 2007). These studies have shown that consumers who are environmentally proactive are ready to take the initiative for purchase of environment-friendly products and also willing to spend extra money on buying of environmentfriendly product.

\section{Research Objectives and Framework}

The objective of this study is to explore the factors that influence the purchase intention of Indian millennials regarding green products. This paper seeks to find out the impact of the explored factor on green product purchase intention. Based on review of literature, it could be stated that intention of consumer regarding purchase of green product gets influenced by several factors. Literature highlighted that attitude towards green brand (ATGB), green brand knowledge (GBK) and willingness to pay (WTP) are the common constructs that affect the buying behavior of consumer towards environment-friendly product. Thus, a conceptual model was proposed to examine the relationship between these factors as an independent variables and green product purchase intention as a dependent variable. The proposed model is shown in figure 1. 
Figure 1. Proposed Model

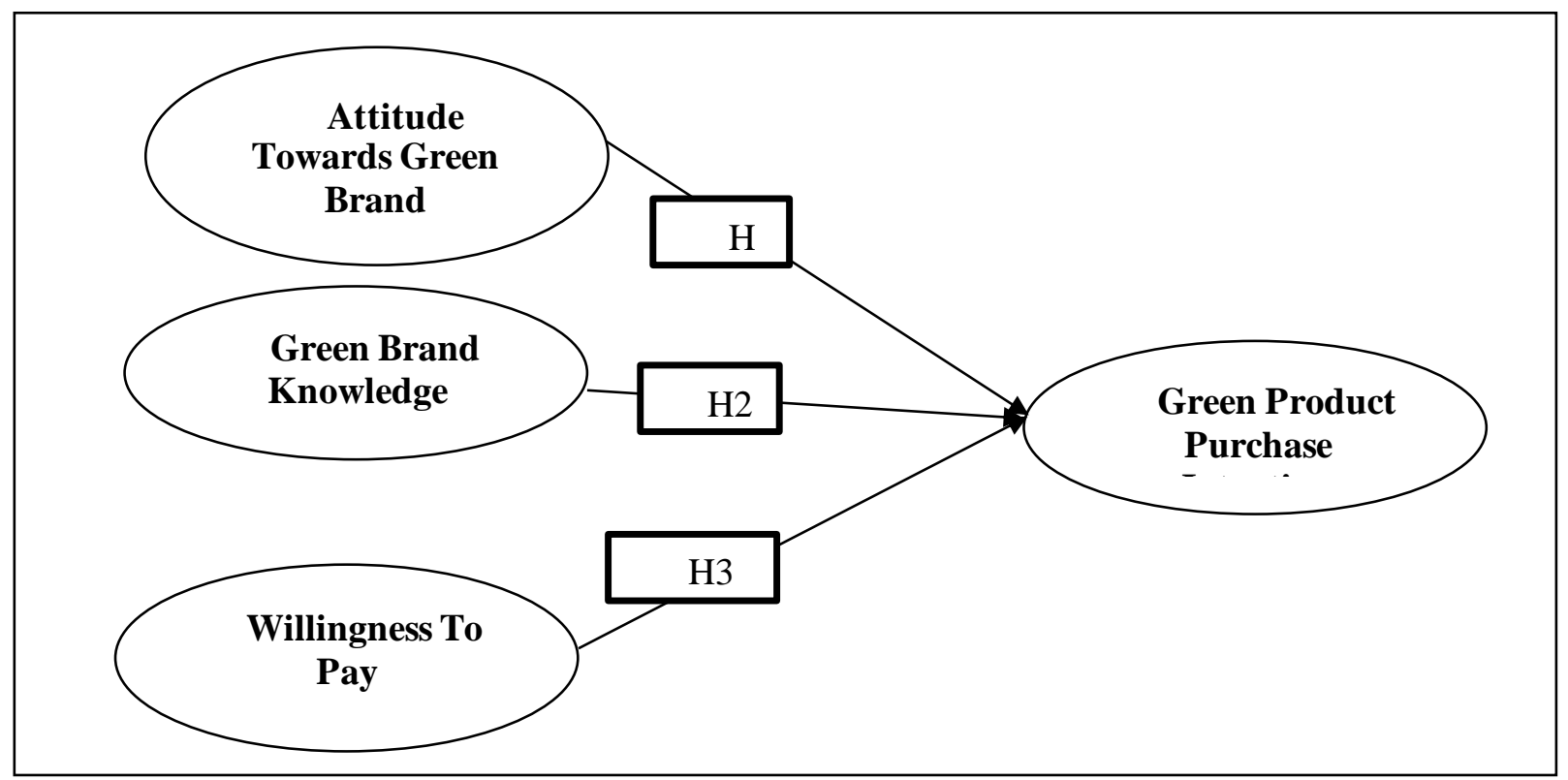

\section{Research Methodology}

For conducting this study, a questionnaire was prepared keeping in mind the proposed conceptual model related to the independent variables namely attitude towards green brand, green brand knowledge, willingness to pay and green product purchase intention as a dependent variable. Attitude towards green brand has 5 items, green brand knowledge has 5 items, willingness to pay has 5 items and green product purchase intention also has 5 items. In total 20 items, were there in questionnaire for which this study used the Likert scale and items were measured on a five-point Likert scale where ( $1=$ strongly disagree, $2=$ disagree, $3=$ neither agree nor disagree, $4=$ agree, $5=$ strongly agree $)$. Further, two statistical software SPSS 25 and AMOS 23 were used in analyzing data.

\subsection{Sample}

Data has been collected from young adults (18-26 years) and specifically from students studying in different courses such as undergraduate and postgraduate courses. The convenience sampling technique was used for gathering data from students studying in Delhi NCR region. Total 400 questionnaires were distributed at hand and out of which 300 questionnaires were received back. From these self-administered questionnaires, 94 responses were invalid and they were eliminated from the analysis. 206 questionnaires were found valid and kept for further analysis as well as questionnaires were also sent to students online through Google form and 170 responses were received. Hence, valid data of 376 respondents were used for the data analysis.

\subsection{Description of sample}

Data were collected from respondents about their demographic profile and Table 1 shows the classification of respondent's profiles in terms of gender, education level and monthly family income (In Rs). 
Table 1. Respondent's Profile

\begin{tabular}{lccc}
\hline & Frequency & Percentage & Cumulative Percentage \\
\hline I. Gender & & & \\
Male & 257 & 68.4 & 68.4 \\
Female & 119 & 31.6 & 100 \\
Total & $\mathbf{3 7 6}$ & $\mathbf{1 0 0}$ & \\
II.Respondent's qualification & & & 56.4 \\
Graduation & 212 & 56.4 & 100 \\
Post-Graduation & 164 & 43.6 & \\
Total & $\mathbf{3 7 6}$ & $\mathbf{1 0 0}$ & \\
III. Family Income (Monthly in Rs) & & & 26.3 \\
Below 20,000 & 99 & 26.3 & 51.6 \\
Between 20,000-40,000 & 95 & 25.3 & 69.9 \\
Between 40,000-60,000 & 69 & 18.3 & 100 \\
Above 60,000 & 113 & 30.1 & \\
Total & $\mathbf{3 7 6}$ & $\mathbf{1 0 0}$ & \\
\hline
\end{tabular}

Table 1 shows that out of total respondents, 257 (69.4\%) were males and $119(31.6 \%)$ were females. From the total respondent's majority of the respondents are graduates $212(56.4 \%)$ and $164(43.6 \%)$ are postgraduates. Similarly, $26 \%$ of respondents have monthly family of less than Rs $20,000,25 \%$ of respondents have monthly family between Rs $20,000-40,000,18 \%$ of respondents have monthly family between Rs 40,000-60,000 and 30\% of respondents have monthly family of above than Rs 60,000.

\section{Results}

Initially, Kaiser-Meyer-Olkin (KMO) was applied as to check the adequacy of data and fitness of data for factor analysis. The KMO measures adequacy of sample for every variable in the model and for the complete model. It determines the appropriateness of your data for factor reduction. The value of KMO lies between 0 and 1 . The general rule for construing the statistics is that higher the value of KMO, data is more appropriate for analysis of factors.

Table 2. KMO and Bartlett's Test

\begin{tabular}{lll}
\hline Kaiser-Meyer-Olkin Measure of Sampling Adequacy. & .890 \\
\hline Bartlett's Test of Sphericity & Approx. Chi-Square & 2790.585 \\
& & \\
\cline { 2 - 3 } & Df & 190 \\
\hline & Sig. & .000 \\
\hline
\end{tabular}

The above table 2 represents the value of KMO as 0.890 that is beyond the threshold limit i.e. 0.7 (Hair et al., 2010). Therefore, the data is adequate for further analysis of the study. The Bartlett's test of sphericity shows the value of chi-square i.e. 2790.585 with degree of freedom (df) 190 at significance level .000 .

\subsection{Factor Analysis}

Factor analysis is a statistical tool which is applied to explore the factors and identify the relationship between the various items of a factor. Exploratory Factor analysis (EFA) helps in structuring the items in a particular factor based on their interdependence. The factor loading of items more than 0.4 (Kline, 
2004; Hair et al., 2010; Malhotra \& Dash, 2011) is considered to be fit for further data analysis. Initially, exploratory factor analysis was performed using principal component analysis (PCA) method. PCA technique is used to get the minimum number of factors and the largest value of variance in the leading factor. In PCA, varimax rotation technique has been used to drive out the factors on the basis of factor loadings. The results of EFA have been presented below in table 3 .

Table 3. Items and Exploratory Factor Analysis

\begin{tabular}{|c|c|c|}
\hline Item & Statement & $\begin{array}{r}\text { Factor } \\
\text { Loadings }\end{array}$ \\
\hline ATGB3 & $\begin{array}{l}\text { I feel that green product's environmental claims are generally } \\
\text { trustworthy }\end{array}$ & 0.761 \\
\hline ATGB4 & Green product's environmental concern meets my expectations & 0.729 \\
\hline ATGB5 & $\begin{array}{l}\text { Green products keep promises and responsibilities for environmental } \\
\text { protection }\end{array}$ & 0.725 \\
\hline ATGB1 & I feel that green product's environmental reputation is generally reliable & 0.668 \\
\hline ATGB2 & $\begin{array}{l}\text { I feel that green product's environmental performance is generally } \\
\text { dependable }\end{array}$ & 0.524 \\
\hline GBK5 & $\begin{array}{l}\text { I purchase green product because it has more environmental benefit } \\
\text { than other products }\end{array}$ & 0.826 \\
\hline GBK4 & I purchase green product because it is environment friendly & 0.803 \\
\hline GBK2 & Green product's environmental performance meets my expectations & 0.606 \\
\hline GBK1 & Going green products could be a beneficial investment in long-term & 0.579 \\
\hline GPPI2 & $\begin{array}{l}\text { I expect to purchase green product in the future because of its } \\
\text { environmental benefits }\end{array}$ & 0.820 \\
\hline GPPI3 & $\begin{array}{l}\text { Overall, I'm glad to purchase green product because it is environment } \\
\text { friendly }\end{array}$ & 0.817 \\
\hline GPPI1 & I intend to buy green product because of my environmental concern & 0.808 \\
\hline GPPI5 & I am willing to make special effort to buy green products & 0.713 \\
\hline GPPI4 & I will prefer green product even if it is not a well-known a brand name & 0.581 \\
\hline WTP5 & $\begin{array}{l}\text { If buying green products results in an additional monthly expenditure } \\
\text { of about } 10 \%, \mathrm{I} \text { am ready to bear it }\end{array}$ & 0.848 \\
\hline WTP3 & It is acceptable for me to pay $10 \%$ extra for green products & 0.838 \\
\hline WTP4 & I would pay $10 \%$ more taxes for an environmental cleanup program & 0.816 \\
\hline WTP2 & $\begin{array}{l}\text { I will prefer green product even if its price is slightly higher than non- } \\
\text { eco-friendly product }\end{array}$ & 0.730 \\
\hline WTP1 & I will prefer green product over non eco-friendly product & 0.474 \\
\hline
\end{tabular}

The above table 4 represents the factor loadings of each item. The discussion related to factor loading concludes that values should be greater than 0.4 ; therefore, all the above values of each item are greater than 0.4. Items having factor loading less than 0.4 were not taken into consideration and rest were 
considered for further analysis. Only one item of green brand knowledge (GBK3) having factor loading less than 0.4 was dropped from the study and the remaining 19 items were considered for the analysis.

\subsection{Reliability and Validity}

Reliability analysis was done to check the consistency of constructs. Cronbach's alpha (CA) is all about measuring the reliability of the scale. It is a tool to measure the consistency which shows how each item of the factor are related to each other. A high value of Cronbach alpha suggests high internal consistency of variable; it is a coefficient of reliability of the variables. The reliability values were measured by using Cronbach's alpha, values which are greater than 0.6 are considered to be appropriate for the measurement of each construct (Hair et al., 2010). The value of each construct was found to be more than 0.6 and the overall reliability of the scale was greater than 0.8 . Further, to assess the reliability and validity of the model, composite reliability (CR), convergent validity and discriminant validity were measured. The composite reliability of all the constructs were greater than 0.7 (Fornell \& Larcker, 1981; Hair et al., 2010) and for convergent validity the values of AVE were also greater than 0.5 (Fornell \& Larcker, 1981; Hair et al., 2010). Discriminant validity (DV) which is square root of AVE is found to be greater than interconstruct correlations (Fornell \& Larcker, 1981; Hair et al., 2010). All the values of reliability and validity are within their threshold limit and are presented in Table 4.

Table 4. Reliability and Validity

\begin{tabular}{|c|c|c|c|c|}
\hline Construct & $\begin{array}{cc}\text { No. } & \text { of } \\
\text { items } & \end{array}$ & $\begin{array}{l}\text { Cronchbach } \\
\text { Alhpa }(\mathrm{CA})\end{array}$ & $\begin{array}{l}\text { Composite } \\
\text { Reliability } \\
\text { (CR) }\end{array}$ & $\begin{array}{c}\text { Average Variance } \\
\text { Extracted (AVE) }\end{array}$ \\
\hline $\begin{array}{l}\text { WTP } \\
\end{array}$ & 5 & .803 & .803 & .758 \\
\hline ATGB & 5 & .715 & .718 & .646 \\
\hline GBK & 4 & .669 & .711 & .582 \\
\hline GPPI & 5 & .789 & .710 & .634 \\
\hline Total & 19 & .887 & & \\
\hline
\end{tabular}

\subsection{Confirmatory Factor Analysis (CFA)}

CFA is the statistical process that is used to examine the variables that how well they signify the number of variables. It is used to confirm the model with measurement theories. CFA confirms on the number of factors of the study and helps in establishing correlation among the construct of the study. Different indices are used to measure the model fit. The variables which are having more than (3) items were considered fit for the CFA and the model fit indices were checked using maximum likelihood method. The values of all the model fit indices were within their threshold limit (Hu \& Bentler, 1999; Hair et al. 2010; Malhotra \& Dash, 2011). The value of CHIIM/DF $=2.575$, GFI $=0.905$, AGFI $=$ $0.874, \mathrm{CFI}=0.906, \mathrm{RMSEA}=0.065, \mathrm{PCLOSE}=0.002$. The details of model fit indices are presented in table 5 and model of CFA is shown in figure 2.

Table 5. Model Fit Indices (CFA)

\begin{tabular}{lcc}
\hline Model fit Indices & Recommended Values & Observed Values \\
\hline CMIN/df & $<3.00$ & 2.575 \\
GFI & $>.90$ & .905 \\
AGFI & $>.80$ & .874 \\
CFI & $>.90$ & .906 \\
RMSEA & $<.070$ & .065 \\
\hline
\end{tabular}

Source: Hu and Banter (1998); Hooper et al. (2008); Hair et al. (2010) 
Figure 2. Confirmatory Factor Analysis

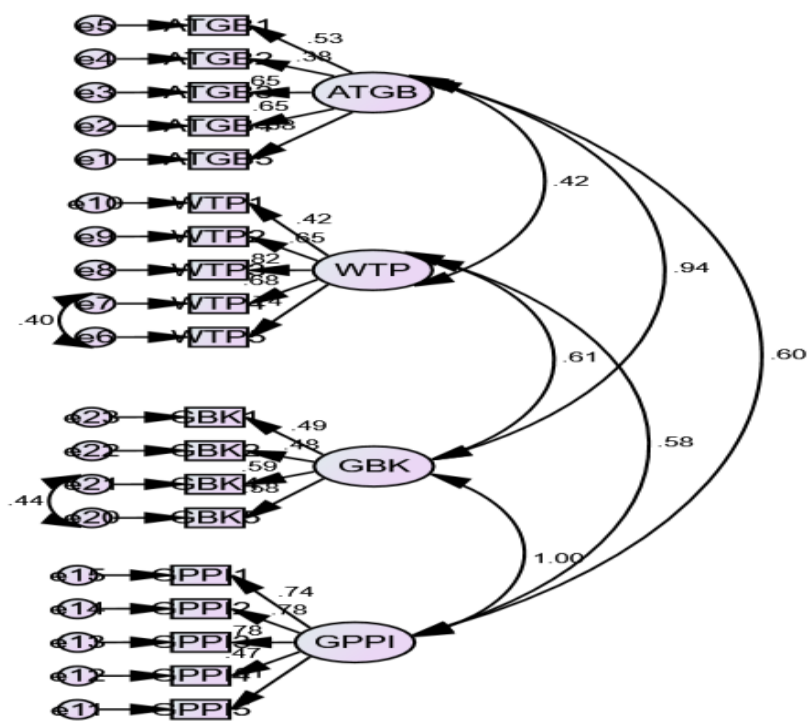

\subsection{Hypothesis Testing using Structural Equation Modeling (SEM)}

Structural Equation Modeling is a statistical tool used to assess the correlation and regression along with establishing structural relationships. SEM is used to examine the relationship between the measured variable and latent variable. In SEM, dependent variables and independent variables are used to see the structural relationship. Results of SEM in $\mathrm{H} 1$ posited that attitude towards green brand has a direct and positive impact on green product purchase intention. As hypothesized in $\mathrm{H} 2$, results showed that green brand knowledge has a direct and positive impact on green product purchase intention. Also, $\mathrm{H} 3$ showed that willingness to purchase has a direct and positive impact on green product purchase intention. The results of SEM are exhibited in table 6 that all hypothesis was supported and path analysis of the model is displayed in figure 3.

Table 6. Hypothesis Testing

\begin{tabular}{lcccc}
\hline & Estimate & S.E & p-value & Label \\
\hline GPPI $\leftarrow$ ATGB & .219 & .049 & $* * *$ & Accepted \\
GPPI $\leftarrow$ GBK & .683 & .094 & $* * *$ & Accepted \\
GPPI $\leftarrow$ WTP & .243 & .038 & $* * *$ & Accepted \\
& & & & \\
\hline
\end{tabular}


Figure 3. Hypothesis and Model Testing using SEM

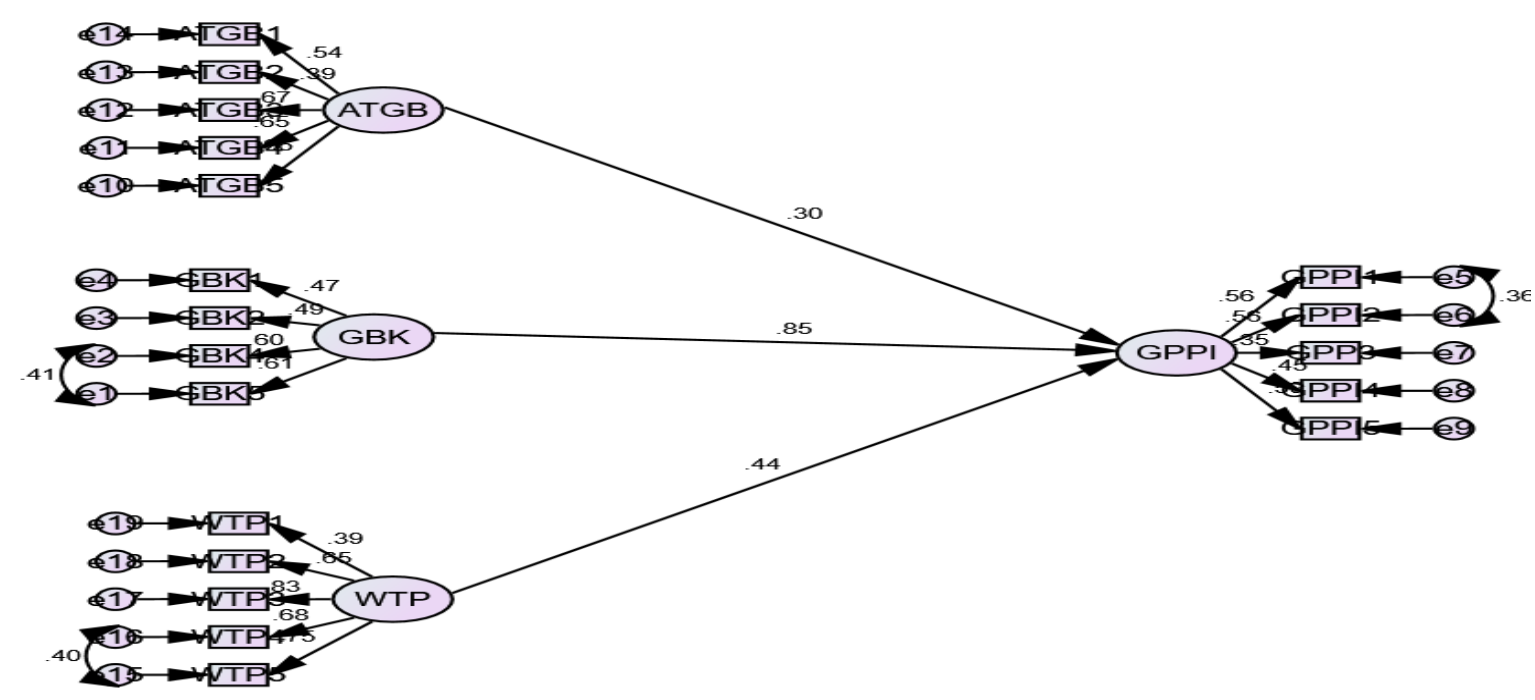

\section{Discussion}

The above study shows the effect of different factors on green product purchase intention. The path analysis shows that attitude towards green brand have a direct and positive impact on green product purchase intention; therefore, $\mathrm{H} 1$ is supported. The findings of the researchers show that consumers who are having a positive attitude of consumer towards green brand are favorable and have a high motivation to purchase green product. The positive attitude towards brand highlights that eco-literate consumers regularly enjoys the utilization of green brand. As previous studies have also shown that environmentally conscious consumers start relating themselves with green brands as an aspect of themselves.

The green brand knowledge was found to be the most powerful and important determinant of green purchase intention as proved in $\mathrm{H} 2$, which shows that green brand knowledge has a direct and positive impact on green product purchase intention. Detailed finding of the research shows that social group, family members and peers having good brand knowledge of green products are encouraging sources that helps consumers to buy environment-friendly product as the one who is close to consumer have already experienced with the purchase of green product. These friends and family members tend to show other consumers that purchasing green product is a fruitful investment for them in the long-run. These groups would also do publicity with word of mouth and help the green product to increase its demand towards fulfilling a better lifestyle.

Willingness to pay has an economical aspect related to expenditure of consumer on purchase of green products. It highlights the consumers capacity to pay an extra premium for green or sustainable products. $\mathrm{H} 3$ posited that willingness to purchase has a direct and positive impact on green product purchase intention. Therefore, it can be stated that consumers are ready to pay some extra premium up to $5 \%$ while purchasing the environment-friendly products. 


\section{Implications}

This study has considered those key aspects of the consumer purchase which influence their decision to buy environment friendly or green product such as green brand knowledge, attitude towards green brand and willingness to pay. From the above research findings, the conclusions can be drawn that all the factors such as attitude towards green brand, green brand knowledge and willingness to pay has a direct and positive impact on green product purchase intention. Furthermore, the above study also highlights that green brand knowledge is one of the most crucial factors that influences consumers in buying eco-friendly products. Additionally, when consumers have awareness about the positive aspects of using green products. It would provide them results similar to good performance of the product and this could change their regular lifestyle into a sustainable lifestyle. In this regard, when the consumers have more information related to a green product that how they are produced, packaged and promoted leads to the adoption of green products in their daily lifestyle. Willingness to pay is the second most significant factor that affects the consumer intention to buy green products. It is preferable for consumers to pay a bit more for green products in order to contribute to environmental protection. If the consumers are aware of green or environment-friendly products, they will be more interested in buying eco-friendly products. Past studies showed that consumers are willing to spend some extra premium against the purchase of eco-friendly products. Furthermore, attitude towards green brand is the third and last important factor that makes an impact on consumer intention to purchase green product. The study also found that the attitude of a consumer affects their buying decision process. It is preferable for the organizations to study the consumers' attitude and focus on the environmentfriendly product to make it more attractive.

\section{Limitations and Future Research Directions}

However, the above study has shown new path but still it has some limitations. Firstly, the data has been collected from the students of Delhi National Capital Region (NCR) and not from other parts of India. Secondly, this study focuses on the purchase intention of younger generation and in particular, students from bachelor's, masters and doctorate as they are potential buyers and also have knowledge about green or environment-friendly product. That's why other population apart from students from were not taken in the study. In future, similar researches can be carried out in other parts of the country to find out the possible outcomes. Also, comparative study can be carried out to assess the purchase intention in urban and rural areas.

\section{References}

[1] Akehurst, G., Afonso, C., \& Gonçalves, H.M. (2012). Re-examining green purchase behavior and the green consumer profile: New evidences. Management Decisions, 50(5), 972-988. DOI: https://doi.org/10.1108/00251741211227726

[2] Allport, G.W. (1935). Attitudes In a handbook of social psychology. Clark University Press, Worcester, MA.

[3] Aman, A.H.L., Harun, A., \& Hussein, Z. (2012). The influence of environmental knowledge and concem on green purchase intention the role of a ttitude as a mediating variable. British Journal of Arts and Social Sciences, 7 (2), 145-167. DOI: 10.18415/ijmmu.v6i2.706

[4] Barber, N., Taylor, C., \& Strick, S. (2009). Wine consumers' environmental knowledge and attitudes: influence on willingness to purchase. International Journal of Wine Research, 1(1), 59-72. DOI: 10.2147/IJWR.S4649

[5] Blackwell, R.D., Miniard, P.W. , \& Engel, J.F. (2006). Consumer Behavior, 1st ed., Thomson Learning Publishers, South Melbourne.

[6] Bowman, J. (2007). Insights into the new Asia n consumers. Media, M2, 1-2. doi.org/10.1108/MIP-032012-0028

[7] Brandon, G., \& Lewis, A. (1999). Reducing hou sehold energy consumption: A qualitative and quantitative study. Journal of Environmental Psychology, 19, 75-85. doi.org/10.1006/jevp.1998.0105 
[8] Bui, My.H.(2005). Environmental marketing: a model of consumer behavior. Proceedings of the Annual Meeting of the Association of Collegiate Marketing Educators, 20-28. Retrieved from http://libroweb.alfaomega.com.mx/book/733/free/ovas_statics/unid3/PDF_Ingles/Environmental_Marketi ng.pdf

[9] C. Eriksson. (2004). Can green consumerism replace en vironmental regulation? A differentiated-products exa mple. Resource andEnergy Economics, 26(3), 281-293. DOI: 10.1016/j.reseneeco.2003.10.001

[10] Chan, R. (2001). Determinants of Chinese consumers' green purchasing behavior. Psychology and Marketing, 18(4), 389-413. DOI: 10.1002/mar.1013

[11] Chang, M.C., \& Wu, C.C. (2015). The effect of message framing on pro-en vironmental behavior intentions: an information processing view. British Food Journal, 117(1), 333-357. DOI: 10.1108/BFJ-09-2013-0247

[12] Cheah, C. M. (2009). A study on consumers green purchasing intention. Master's thesis. Malaysia: College of Business, University Utara Malaysia.http://etd.uum.edu.my/1778/2/1.Cheah_Ching_Mun.pdf

[13] Cheah, I., \& Phau, I. (2011). Attitudes towards environmentally friendly products: The influence of ecoliteracy, interpersonal influence and value orientation. Marketing Intelligence \& Pla nning, 29(5), 452-472. DOI: $10.1108 / 02634501111153674$

[14] Chen, Y.S., \& Chang, C.H. (2012). Enhance green purchase intentions: the roles of green perceived value, green perceived risk, and green trust. Management Decision, 50(3), 502-520. DOI: $10.1108 / 00251741211216250$

[15] Coddington, W. (1990). 'It's no fad: environmentalism is now a fact of corporate life. Marketing News, 15 (October), 7 .

[16] Connell, K.Y.H. (2010). Internal and external barriers to eco-conscious apparel acquisition. International Journal of Consumer Studies, 34(3), 279-286. doi.org/10.1111/j.1470-6431.2010.00865.x.

[17] D’Souza, C., Taghian, M., Lamb, P., \& Peretiatkos, R. (2006). Green products and corporate strategy: An empirical investigation. Society and Business Review, 1(2), 144-157. DOI: 10.1 108/17465680610669825

[18] D’Souza, C., Taghian, M., Lamb, P., \& Peretiatkos, R. (2007). Green decisions: demographics and consumer understanding of environmental labels. International Journal of Consumer Studies, 31(4), 371376. DOI: 10.1111/j.1470-6431.2006.00567.x

[19] Essoussi, L.H., \& Linton J.D. (2010). New or recycled products: how much are consumers willing to pay. Journal of Consumer Marketing, 27(5), 458 -468. DOI: 10.1108/07363761011063358

[20] Eze, U.C., \& Ndubisi, N.O. (2013). Green buyer behaviour: Evidence from Asia consumers. Joumal of Asian and African Studies, 48(4),413-426. https://doi.org/10.1177\%2F0021909613493602

[21] Felix, R., \& Braunsberger, K. (2016). I believe therefore I care: the relationship between religiosity, environmental attitudes, and green product purchase in Mexico. International Marketing Review, 33(1), 137-155. DOI: 10.1108/IMR-07-2014-0216

[22] Fishbein, M., \& Ajzen, I. (1975). Belief, attitude, intention and behavior: An introduction to theory and research reading. MA: Addison-Wesley.

[23] Flamm, B. (2009). The impacts of environmental knowled ge and attitudes on vehicle ownership and use. Transportation Research Part D: Transport and Environment, 14(4), 272-279. DOI: 10.1016/j.trd.2009.02.003

[24] Follows, S. B., \& Jobber, D. (2000). Environmentally responsible purchase behaviour: A test of a consumer model. European Journal Market, 34, 723-746. http://dx.doi.org/10.1108/03090560010322009

[25] Fornell, C., \& Larcker, D. F. (1981). Evaluating structural equation models with unobservable variables and measurement errors. Journal of Marketing Research, 18(1), 39-50.

[26] Fraj-Andrés, E., \& Martínez-Salinas, E. (2007). Impact of environmental knowledge on ecological consumer behaviour: an empirical a nalysis. Journal of International Consumer Marketing, 19(3), 73-102. https://doi.org/10.1300/J046v19n03_05

[27] Ga larraga, I., Gonzalez-Eguino, M., \& Markandya, A. (2011). Willingness to pay and price ela sticities of demand for energyefficient appliances: Combining the hedonic approach and demand systems. Energy Economics, 33, 66-74. DOI: 10.1016/j.eneco.2011.07.028

[28] Ga napathy, S.P., Natarajan, J., Gunasekaran, A., \& Subramanian, N. (2014). Influence of eco innovation on Indian manufacturing sector su stainable performance. International Journal of Su stainable Development and World Ecology, 21(3), 198-209. doi: 10.1080/13504509 
[29] Geyer-Allely, E., \& Zacarias-Farah, A. (2003). Policies and instruments for promoting susta inable household consumption. Journal of Cleaner Production, 11(8), 923-926. DOI: 10.1016/S09596526(02)00156-7

[30] Grant, J. (2008). Green marketing. Stra tegic Direction, 24(6), 25-27.

[31] Gupta,S., \& Ogden, D.T. (2009). To buy or not buy: a social dilemma perspectiveon green buying. Joumal of Consumer Marketing, 26(6), 376-391. doi/10.1108/07363760910988201

[32] Hair, J. F., Black, W. C., Babin, B. J., and Anderson, R. E. (2010). Multivariate Data Analysis (7th Ed.). Upper Saddle River, NJ: Pearson Prentice-Hall.

[33] Hansla, A., Gamble, A., Juliusson, A., \& Garling, T. (2008). Psychological determinants of attitude towards and willingness to pay for green electricity. Energy Policy, 36, 768-774. DOI: 10.1016/j.enpol.2007.10.027

[34] Hartmann, P., \& Ibanez, V.A. (2006). Green value added. Marketing Intelligence and Planning, 24(7), 673680. doi: $10.1108 / 02634500610711842$

[35] Hassan, S.H. (2014). The role of isla mic values on green purchase intention. Journal of Islamic Marketing, 5(3), 379-395. doi.org/10.1108/JIMA-11-2013-0080

[36] Hu, L. T., \& Bentler, P. M. (1999). Cutoff criteria for fit indixes in covariance structure analysis: Conventional criteria versus new a lternatives. Structural Equation Modelling: A Multidisplinary Joumal, 6(1), 1-55

[37] Huang, Y.C., Yang, M., \& Wang, Y.C. (2014). Effects of green brand on green purchase intention. Marketing Intelligence and Planning, 32(3), 250-268. doi.org/10.1 108/MIP-10-2012-0105

[38] Iman, K., \& Zainuddin, Y. (2011). The Impact of Media Exposure on Intention to Purchase Green Electronic Products a mongst Lecturers. International Journal of Business and Management, 6(3). DOI: 10.5539/ijbm.v6n3p240.

[39] Ira vani M. R., Zadeh M. S., Forozia A., Shafaruddin, N., \& Mahroeian, H. (2012). Study of factors affecting young consumers to choose green products. Journal of Basic and Applied Scientific Res earch, 2(6), 55345544. ISSN 2090-4304

[40] Joshi, Y., \& Rahman, Z. (2015). Factors affecting green purchasebehaviour and future research directions. International Strategic Management Review, 3, 128-143. https://doi.org/10.1016/j.ism.2015.04.001

[41] Juwaheer, T.D., Pudaruth, S., \& Noyaux, M.M.E. (2012). Analysing the impact of green marketing stra tegies on consumer purchasing patterns in Mauritius. World Journal of Entrepreneurship, Management and Sustainable Development, 8(1),3659. DOI: 10.1108/20425961211221615

[42] Keller, K.L. (1993). Conceptualizing, measuring, and managing customer-based brand equity', Joumal of Marketing, 57(1), 1-22.https://doi.org/10.1177\%2F002224299305700101

[43] Kirmani, M.D., \& Khan, M.N. (2016). Environmental concern to attitude towards green products: Evidences from India. Serbian Journal of Management, 11(2), 159-179. DOI: 10.5937/sjm1 1-9241

[44] Kline, R. B. (2004). Principles and practice of structural equation modelling (2ed.). New York: Guildford.

[45] Konuk, F.A. (2015). The effects of price consciousness and sale proneness on purchase intention towards expira tion date-based priced perishable foods. British Food Journal, 117(2), 793-804. DOI: 10.1108/BFJ10-2013-0305

[46] Kotler, P., \& Armstrong, G. (2001) Principles of Marketing (9th Ed)., New Jersey: Prentice Hall, Inc.

[47] La roche, M., Bergeron, J., \& Barbaro-Forleo, G. (2001). Targeting consumers who are willing to pay more for environmentally friendly products. Journal of Consumer Marketing, 18(6), 503-520. http://dx.doi.org/10.1108/EUM0000000006155

[48] Le Gall-Elly M.(2009). Definition, Measurement, and Determinants of the Consumer's Willingness to Pay: a Critical Synthesis and Avenues for Further Research. Recherche et Applications en Marketing, 24(2), 91112. https://hal.archives-ouvertes.fr/hal-00522828/document

[49] Lee, J.S., Han, H., Hsu, L.T., \& Kim, Y. (2010). Understanding how consumers view green hotels: how a hotel's green image can influence behavioural intentions. Journal of Sustainable Tourism, 18(7), 901-914. https://doi.org/10.1080/09669581003777747

[50] Lee, K. (2008). Opportunities for green marketing: Young consumers. Marketing Intelligent and Planning, 26, 573-586. http://dx.doi.org/10.1108/02634500810902839

[51] Malhotra, N. K., a nd Dash, S. (2011). Marketing Research: An Applied Orientation(6th Ed.). Noida, USA: Pearson. 
[52] Marcus, A., \& Fremeth, A.R. (2009). Green management matters regardless. Academy of Management Perspectives, 23(3), 17-26. doi.org/10.5465/amp.2009.43479261

[53] Moser, A. K. (2015). Thinking green, buying green? Drivers of pro-environmental purchasing behavior. Journal of Consumer Marketing, 32(3), 167-175./doi.org/10.1108/JCM-10-2014-1179

[54] Mostafa, M. (2009). Shades of green: A psychographic segmentation of the green consumer in Kuwait using self-organizing maps. Expert Systems with Applications, 36(8), 11030-11038. DOI: 10.1016/j.eswa.2009.02.088

[55] Mourad M., \& Ahmed Y.S.E. (2012). Perception of green brand in an emerging innovative market. European Journal of Innovation Management, 15(4), 514-537. DOI: 10.1108/14601061211272402

[56] Myburgh-Louw, J. and O'Shaughnessy, N.J. (1994) Consumer Perception of Misleading and Deceptive Claims on the Packaging of "Green" Fast Moving Consumer Goods. In: Achrol, R. and Mitchell, A., Eds., AMA Summer Educators' Conference Proceedings, Vol. 5, American Marketing Asso ciation, Chicago, 344-353. DOI: $10.4236 /$ jss.2015.310013

[57] Ng, S., \& Paladino, A. (2009). Examining the Influences of Intention to Purchase Green Mobile Phones Among Young Consumers: An Empirical Analysis. ANZMAC, 1-8. https://www.semanticscholar.org/paper/Examining-the-Influences-of-Intentions-to-Purchase-NgPaladino/7a8207c8129a4298acf6fbc252bca43402d206df

[58] Nik Abdul Rashid, NR. (2009). Awareness of Eco-label In Malaysia's Green Marketing Initiative. International Journal of Business a nd Management, 4(8), 132 - 141. DOI: 10.5539/ijbm.v4n8p132

[59] Norazah, M.S. (2013a). Green products purchases: structural relationship sof consumers' perception of ecolabel, eco-brand a nd environmental a d vertisement. Journal Sustainable Science and Management, 8(1), 1 10 .

[60] Norazah, M.S. (2013b). Young consumer ecological behaviour: effects of environmental knowledge, hea lthy food, and healthy way of life with the moderation of gender and age. Management of Environmental Quality: An International Journal, 24(6), 726-737.http://dx.doi.org/10.1108/MEQ-02-2013-0010

[61] Norazah, M.S. (2013c). Green awareness effects on consumer's purchasing decision: some insights from Malaysia. International Journal of Asia Pacific Studies, 9, 49-63. https://ijaps.usm.my/wpcontent/uploads/2013/07/Art3.pdf

[62] Norazah, M.S., \& Norbayah, M.S. (2015). Consumption values and consumer environmental concem of green products. International Journal of Sustainable Development and World Ecology, 22, 269-278. doi.org/10.1080/13504509.2015.1013074

[63] Okada, E.M., \& Mais, E.L, (2010). Framing the 'Green' alternative for environmentally conscious consumers. Sustainability Accounting, Management and Policy Journal, 1(2), 222 - 234. DOI: $10.1108 / 20408021011089257$

[64] Oliver, J.D., \& Lee, S.H. (2010). Hybrid car purchase intentions: A cross-cultural analysis. Joumal Consumer Marketing, 27(2), 96-103. DOI.10.1108/07575761011027204

[65] Padel, S., \& Foster, C. (2005). Exploring the gap between attitudes and behaviour: understanding why consumers buy or do not buy organic food. British Food Journal, 107(8), 606-625. DOI: $10.1108 / 00070700510611002$

[66] Pagia slis, A., \& Krontalis, A.K. (2014). Green consumption behavior antecedents: environmental concem, knowledge, and beliefs. Psychology \& Marketing, 31(5), 335-348. doi.org/10.1002/mar.20698

[67] Paul, J., Modi, A., \& Patel, J. (2016). Predicting green product consumption using theory of planned behavior and reasoned action. Journal of Retailing and Consumer Services, 29, 123134. https://doi.org/10.1016/j.jretconser.2015.11.006

[68] Peattie, K. (2010). Green consumption: behaviour and norms. Annual Review of Environment and Resources, 35(1), 195. doi.org/10.1146/annurev-environ-032609-094328

[69] Punitha, S., \& Rahman, A.A. (2011). Antecedents of Green Purchasing Behavior among Malaysian Consumers. International Business Management, 5(3), 129-139. DOI:10.3923/ibm.201 1.129.139

[70] Rokicka, E. (2002). Attitudes toward natural environment. a study of local community dwellers. International Journal of Sociology, 32(3), 78-90. DOI:10.1080/15579336.2002.11770256

[71] Reynolds, T., Kolodinsky, J., \& Murray, B. (2012). Consumer preferences and willingness to pay for compact fluorescent lighting: Policy implications for energy efficiency promotion in Saint Lucia. Energy Policy, 41,712-722.DOI: 10.1016/j.enpol.2011.11.035 
[72] Schiffman, L.G., \& Wisenblit, J. (2014). Consumer Behaviour (11 th Ed.). Pearson Education Inc., New Jersey.

[73] Schultz, P.W., \& Zeleny, L.C. (2000). Promoting environmentalism. The Journal of Social Issues, 56,443457.https://web.stanford.edu/ kcarmel/CC_BehavChange_Course/readings/Additional\%20Resources/J\% 20Soc\%20Issues\%202000/delivery\%253Bid=2gms91ynk0pcr.pdf

[74] Solomon, M.R. (2014). Consumer Behaviour: Buying, Having, and Being (1 1th Ed.). Pea rson Education Inc., New Jersey.

[75] Soyez, K. (2012). How national cultural values affect pro-environmental consumer behavior. International Marketing Review, 29(6), 623-646. doi.org/10.1108/02651331211277973

[76] Suplico, L.T., \& Salle, D.L (2009). Impact of green marketing on the students' purchase decision. Joumal of International Business Research, 8(2), 71-80. https://globaljournals.org/GJMBR_Volume17/2Influence-of-Green-Marketing.pdf

[77] Tanner, C., \& Kast, S.W. (2003). Promoting sustainable consumption: determinants of green purchases by Swiss consumers. Psychological Marketing, 20, 883-902. http://dx.doi.org/10.1002/mar.101

[78] Teng, L. (2009). A comparison of two types of price discounts in shifting consumers' a ttitude and purchase intentions. Journal of Bu siness Research, 62(1), 14-21. DOI:10.1016/j.jbusres.2007.11.014

[79] Thogersen, J., Dutra de Barcellos, M., Gattermann Perin, M., \& Zhou, Y. (2015). Consumer buying motives and attitudes towards organic food in two emerging markets. International Marketing Review, 32(3/4), 389413. DOI: $10.1108 /$ IMR-06-2013-0123

[80] Tsen, C., Phang, G., Ha san, H., \& Buncha, M.R. (2006). Going green: a study of consumers’ willingness to pay for green products in Kota Kinabalu. International Journal of Business and Society, 7(2), 40 -54.

[81] Wolsink, M. (2007). Wind power implementation: the nature of public attitudes: equity and fairness instead of 'backyard motives. Renewable and Sustainable Energy Reviews, 11(6), 1188-1207. doi:10.1016/j.rser.2005.10.005

[82] Yadav, R., \& Pathak, G.S. (2016). Young consumers' intention towards buying green products in a developing na tion: extending the theory of planned behavior. Journal of Cleaner Production, 135(1), 732739. DOI 10.1016/j.jclepro.2016.06.120 